\title{
Impact Teaching: Lead or Be Left Behind
}

Gisele Moss, Lamar University, USA

Jeff Dyson, Lamar University, USA

Alicen Flosi, Lamar University, USA

\begin{abstract}
This paper examines opportunities to improve student achievement by examining teaching effectiveness. It suggests practices that instructors use in their course delivery to encourage interest in the subject and create a connection between the subject and global competitiveness. This paper examines the challenges that post-secondary instructors face in course and class design for delivering impressionable and long-lasting academic instruction that gives students a competitive edge. Today's students must lead or be left behind. They face unique challenges and have different educational needs. Instructors must align courses with the requirements of the society of the future, which will demand new combinations of skills and abilities. Recognizing that student achievement is inextricably linked to teaching effectiveness, the authors surveyed students about their favorite professor and class and why that person and class were selected. Survey results were analyzed to identify effective teaching characteristics.
\end{abstract}

Keywords: teaching effectiveness; teaching delivery; teaching style

\section{INTRODUCTION}

$\mathrm{n}$ order to drive student achievement, instructors at the college and university level are often faced with the task of imparting a great deal of information in a short amount of time. With the additional demands of research and service placed on instructors, there is little time to reflect on the pedagogical techniques and strategies of teaching that have the greatest impact on students' retention. This study addresses the factors that make an instructor an impact teacher.

\section{LITERATURE REVIEW}

University instructors, as perpetual students, have studied with many teachers. They know the qualities and skills that make teachers first-rate. There has also been a great deal of research identifying and documenting those qualities. Therefore, rather than catalog the traditional findings, this literature review will briefly recount past research and then focus on contemporary research, which, due to changes in the global competitive environment, changes in the educational environment, and new technologies, demands additional skills from instructors.

\section{General Traits That Effective Teachers Share}

Past research indicates that impact teachers all share a solid general education background, a deep knowledge of their subject matter, familiarity with numerous pedagogical approaches, strong communication skills, and effective organizational skills (Nieto, 2006, 463). Research findings also suggest that changes in the student body, the global competitive environment, and technology introduce new requirements for teachers to be effective.

Many articles have studied the use of humor's impact on teaching and find that students have a more positive attitude toward the learning process when humor is used. They are often more relaxed and can more easily relate to the instructor. One study of undergraduate students was performed by Garner (2006), who found that humor did increase student pleasure and content retention. Wanzer, et. al. (2006) found that when used appropriately, humor can improve student attention and enjoyment. 


\section{Today's Students}

It is interesting to note that, regardless of the setting, studies on impact teaching often have the same results. For example, a survey of nine women completing detention sentences in a halfway house found they appreciated hands-on experimentation with concepts, encouragement in accessing various learning styles, and compassion and understanding (Mageehon, 2006). A study of 84 final year medical students found the following factors were important: use of simple and clear language, approachability, use of constructive feedback, encouragement of critical thinking, and introducing students to additional resources.

In a recent press release, a U.S. Department of Education official stated that American students are “...treading the waters of academic achievement while other countries' students are swimming faster and farther." Research into impact teaching styles and personalities of teachers is perhaps more important now, when the lives of students are so different from previous generations. McWilliam states, "The challenge for academic teachers is to promote and support a culture of teaching and learning that parallels a post-millennial social world in which supply and demand is neither linear nor stable, in which labour is shaped by complex patterns of anticipations, opportunities, time and space, and in which new combinations of 'creative' skills and abilities are increasingly in demand" (2008). To prepare students for lives in which they perform fewer routine tasks and that require creative, problem-solving skills, McWilliam (2008) states that teachers need to take on the role of "meddler in the middle" rather than that of lecturer or guide. The "meddler in the middle" role means:

- Less time giving instructions and more time spent being a usefully ignorant co-worker in the thick of the action

- Less time spent being a custodial risk minimizer and more time spent being an experimenter and risk-taker

- Less time spent being a forensic classroom auditor and more time spent being a designer, editor and assembler

- $\quad$ Less time spent being a counselor and more time spent being a collaborative critic and authentic evaluator (McWilliam, 2008, p. 265)

This new role changes teachers from ones who are the source of all knowledge to "co-creaters" in adding value.

Table 1 identifies the characteristics of the Net Generation and teaching adaptations that can be made to adjust to those characteristics (Skiba \& Barton, 2006).

Table 1: Characteristics Of Net Generation

\begin{tabular}{|l|l|}
\hline \multicolumn{1}{|c|}{ Characteristics of the Net Generation } & \multicolumn{1}{c|}{ Teaching Adaptations for learning needs of the Net Generation } \\
\hline Fierce independence & Digital literacy \\
\hline Emotional and intellectual openness & Experiential and engaging \\
\hline Inclusion & Interactivity and collaboration \\
\hline Free expression and strong views & Immediacy, connectivity and communications \\
\hline Innovation & \\
\hline Preoccupation with maturity & \\
\hline Investigations & \\
\hline Immediacy & \\
\hline Sensitivity to corporate interest & \\
\hline Authentication and trust & \\
\hline
\end{tabular}

\section{Distinctiveness Of Teaching At The Post-Secondary Level}

Teaching at the university level offers unique opportunities. One example is large lecture-based classes. Long and Coldren (2006) studied the interpersonal relationships between instructors and students in large classes. They found students are impacted more favorably by a personal teaching style. 
They suggest that adoption of the following methods will encourage an interpersonal relationship between the instructor and students and thereby improve students' attention and motivation to learn. As an instructor you should:

- $\quad$ Explain your thinking, not just your answers

- $\quad$ Laugh at your mistakes and use them as opportunities for learning

- $\quad$ Create a team atmosphere

- $\quad$ Use personal anecdotes, but make them professionally relevant

- Use engaging nonverbal cues

- Talk to, not at, your students

- $\quad$ Get excited (Long \& Coldren, 2006, 242)

\section{Methods Of Information Delivery}

The advantage of selecting teaching as a profession is that teachers can, to some extent, select the methods they choose to use to impart information. However, it is important to select methods that work for the teacher and impact the student.

Slides are being used more often by instructors now that presentation software such as MS PowerPoint has become easier to use and publishers often include slideshows with textbooks. Klemm (2007) explains how slide shows become a trap for bad teaching by promoting a passive, entertainment atmosphere where little student engagement is required. Interaction between the students and teacher may be reduced or eliminated. The final problem Klemm (2007) notes is that students obtain hard copies of the slides and therefore do not have to take their own notes; taking notes would allow them to further consider the information.

Klemm (2007) concludes that slides can be effective if their use is limited and if they are accompanied by discussion and application of the material. In addition, the temptation to distribute the entire slideshow to students should be resisted and only "certain content-rich slides should be distributed."

\section{STUDY}

\section{A Personal Essay}

As part of an essay project in an entrepreneurship course at a university, graduate and undergraduate students were asked to identify their favorite class and the instructor who had the greatest impact and to write about why they selected that instructor or class. Five broad categories were identified by the authors when reviewing the essays:

1. Behavior required from students: participation, engagement/critical thinking, preparation

2. Preferred classroom technique: lecture and test, case approach, speakers/field trips, extra credit

3. Instructor personality characteristics: willingness to help students, display of love of teaching and subject, positive attitude, humor included in class, respect for students, patience, approachability, smiles/friendly, remembers name

4. Relating classroom to profession: experience in subject, background/knowledge of subject, relates class to real world

5. Teaching delivery: interacts with students, explains well, interesting/entertaining, prepared, passionate about subject

\section{RESULTS}

One hundred thirty-two undergraduate students completed essays. Table 2 shows the responses based on the five categories. Eighteen graduate students completed the essay. Table 3 shows the responses from graduate students based on the same categories. 


\section{Analysis}

A few items were particularly prominent in the undergraduate student essays. The students were impacted most by instructors who are interesting and/or entertaining (46\%), who relate material to the real world (45\%), who are willing to help students (40\%), who have a background/knowledge of the subject (25\%), who explain well (23\%), who have experience in the subject (20\%), who are passionate about the subject (20\%) and who use humor (27\%). Students also like to be challenged in class (27\%). Passion based on experience or knowledge of the topic and an entertaining delivery method give students good memories of a teacher or class.

There was consensus on fewer items in the graduate student essays; however, many of the top responses were the same as the undergraduate results. The graduate students in the study prefer instructors who are interesting and/or entertaining (33\%), who relate material to the real world (44\%), and who are passionate about the subject (39\%). Graduate students also like to be challenged in class (28\%) and prefer the case approach (22\%), which is used heavily in the M.B.A. program. Again, interesting instructors who relate material to the real world with passion made an impact on students.

Table 2: Undergraduate Responses

\begin{tabular}{|c|c|c|}
\hline Item & Frequency & Percentage \\
\hline \multicolumn{3}{|l|}{ Behavior required from students: } \\
\hline Participation & 7 & $14 \%$ \\
\hline Engagement/critical thinking & 5 & $8 \%$ \\
\hline Challenged & 16 & $27 \%$ \\
\hline Preparation & 4 & $3 \%$ \\
\hline \multicolumn{3}{|l|}{ Preferred classroom technique: } \\
\hline Lecture and test & 6 & $11 \%$ \\
\hline Case approach & 6 & $10 \%$ \\
\hline Speakers/field trips & 2 & $2 \%$ \\
\hline Extra credit & 2 & $2 \%$ \\
\hline \multicolumn{3}{|l|}{ Instructor personality characteristics: } \\
\hline Willing to help students & 22 & $40 \%$ \\
\hline Display love of teaching and subject & 8 & $17 \%$ \\
\hline Positive attitude & 2 & $11 \%$ \\
\hline Humor included in class & 17 & $27 \%$ \\
\hline Respect for students & 5 & $8 \%$ \\
\hline Patience & 1 & $5 \%$ \\
\hline Approachability & 6 & $14 \%$ \\
\hline Smiles/friendly & 6 & $10 \%$ \\
\hline Remembers name & 6 & $10 \%$ \\
\hline \multicolumn{3}{|l|}{ Relating classroom to profession: } \\
\hline Experience in subject & 12 & $20 \%$ \\
\hline Background/knowledge of subject & 14 & $25 \%$ \\
\hline Relates class to real world & 23 & $45 \%$ \\
\hline \multicolumn{3}{|l|}{ Teaching delivery: } \\
\hline Interacts with students & 2 & $12 \%$ \\
\hline Explains well & 11 & $23 \%$ \\
\hline Interesting/entertaining & 26 & $46 \%$ \\
\hline Prepared & 5 & $8 \%$ \\
\hline Passionate about subject & 8 & $20 \%$ \\
\hline
\end{tabular}


Table 3: Graduate Responses

\begin{tabular}{|c|c|c|}
\hline Item & Frequency & Percentage \\
\hline \multicolumn{3}{|l|}{ Behavior required from students: } \\
\hline Participation & 2 & $11 \%$ \\
\hline Engagement/critical thinking & 3 & $17 \%$ \\
\hline Challenged & 5 & $28 \%$ \\
\hline Preparation & 2 & $11 \%$ \\
\hline \multicolumn{3}{|l|}{ Preferred classroom technique: } \\
\hline \multicolumn{3}{|l|}{ Lecture and test } \\
\hline Case approach & 4 & $22 \%$ \\
\hline \multicolumn{3}{|l|}{ Speakers/field trips } \\
\hline \multicolumn{3}{|l|}{ Extra credit } \\
\hline \multicolumn{3}{|l|}{ Instructor personality characteristics: } \\
\hline Willing to help students & 3 & $17 \%$ \\
\hline Display love of teaching and subject & 3 & $17 \%$ \\
\hline Positive attitude & 2 & $11 \%$ \\
\hline Humor included in class & 2 & $11 \%$ \\
\hline \multicolumn{3}{|l|}{ Respect for students } \\
\hline \multicolumn{3}{|l|}{ Patience } \\
\hline Approachability & 1 & $6 \%$ \\
\hline Smiles/friendly & 2 & $11 \%$ \\
\hline \multicolumn{3}{|l|}{ Remembers name } \\
\hline \multicolumn{3}{|l|}{ Relating classroom to profession: } \\
\hline Experience in subject & 1 & $6 \%$ \\
\hline \multicolumn{3}{|l|}{ Background/knowledge of subject } \\
\hline Relates class to real world & 8 & $44 \%$ \\
\hline \multicolumn{3}{|l|}{ Teaching delivery: } \\
\hline Interacts with students & 3 & $17 \%$ \\
\hline Explains well & 3 & $17 \%$ \\
\hline Interesting/entertaining & 6 & $33 \%$ \\
\hline \multicolumn{3}{|l|}{ Prepared } \\
\hline Passionate about subject & 7 & $39 \%$ \\
\hline
\end{tabular}

\section{LIMITATIONS AND FUTURE RESEARCH}

The directions provided to the students for the essay were open-ended. Students could comment on any instructor characteristics, instructor behaviors, teaching methodologies or class observances they liked, and they could be general or specific. In addition, when culling data from the essays and designing categories, there was some overlap. Behaviors or characteristics could have been noted in more than one category in some instances. Also, other students may have felt like characteristics/behaviors are important, but they simply did not think to include them. The study requested students to consider classes or teachers who were their "favorite." This means that, for some reason, the instructor or class made an impact on them that was memorable. This study does not investigate "effective teaching".

Future studies should consider both effective teaching strategies and characteristics of good teachers to try to develop best practices for teaching at the post-secondary level. As the world and the students change, teaching will need to change. Identifying the impact of teaching strategies and characteristics of memorable teachers can improve the entire process.

\section{AUTHOR INFORMATION}

Gisele J. Moss, Ph.D., CPA, is the Pat Wheat Faculty Scholar in Business, Lamar University. She is an Associate Professor of Accounting and received her Ph.D. from Louisiana State University. Her research interests include financial/managerial reporting issues and accounting education. 
Jeff Dyson is the coordinator of the Lamar University's Institute for Entrepreneurial Studies and an instructor in its Management and Marketing department. He received his MBA from Lamar University. His research interests include entrepreneurship, human resource management, and effective teaching.

Alicen Flossi, Ph.D., is an instructor in the Information Systems and Analysis Department at Lamar University. She received her Ph.D. from Nova Southeastern University. Her research interests include human/computer interaction, effective teaching, and change management.

\section{REFERENCES}

1. Y. Alweshahi, D. Harley, and D. Cook, (2007). Student's perception of the characteristics of effective bedside teachers. Medical Teacher, 29, 204-9.

2. R. Dunn, A. Honigsfeld, L. Doolan, L. Bostrom, K. Russo, M. Schiering, B. Suh, and H. Tenedero, (2009). Impact of learning-style instructional strategies on students' achievement and attitudes: perceptions of educators in diverse institutions. Clearing House, 82(3), 135-40.

3. A. Estes, R. Welch, and S. Ressler, (2006). Teaching Lessons Learned: the assessment of teaching. Journal of Professional Issues in Engineering Education and Practice, January 2006, 2-10.

4. $\quad$ R. Garner, (2006). Humor in Pedagogy. College Teaching, 54(1), 177-80.

5. W. Klemm, (2007). Computer slide shows: a trap for bad teaching. College Teaching, 55(3), 124.

6. A. Mageehon, (2006). What makes a "good" teacher "good": women in transition from prison to community reflect. The Journal of Correctional Education, 57(2), 145-57

7. $\quad$ R. Mahon, (2005). Ten Tips for Teachers. The Clearing House, 265-6.

8. E. McWilliam, (2008). Unlearning how to teach. Innovations in Education and Teaching International, 45(3), 263-269.

9. S. Nieto, (2006). Solidarity, courage and heart: what teacher educators can learn from a new generation of teachers. Intercultural Education, 17(5), 457-73.

10. R. Rosenzweig, (2005). Interview with exemplary teachers: Nancy A. Hewitt. The History Teacher, 38(3), 371-84.

11. D. Skiba and A. Barton, (2006). Adapting your teaching to accommodate the net generation of learners. Online Journal of Issues in Nursing, 11(2).

12. T. Tomcho and R. Foels, (2008). Assessing effective teaching of psychology: a meta-analytic integration of learning outcomes. Teaching of Psychology, 35(4), 286-96.

13. B. Tucker, S. Jones, and L. Straker, (2008). Online student evaluation improves course experience questionnaire results in a physiotherapy program. Higher Education Research \& Development, 27(3), 28196.

14. M. Wanzer, A. Frymier, A. Wojtaszczyk and T. Smith, (2006). Appropriate and inappropriate Uses of humor by teachers. Communication Education, 55(2), 178-96. 